\title{
HIGH SENSITIVE C-REACTIVE PROTEIN IN CEREBROVASCULAR ISCHEMIA
}

\author{
Padmalatha $P^{1}$, Neeraja $K^{2}$
}

${ }^{1}$ Assistant Professor, Department of Medicine, Andhra Medical College, Visakhapatnam.

${ }^{2}$ Civil Surgeon Specialist, Department of Medicine, ESI Hospital, Visakhapatnam.

\section{ABSTRACT}

\section{BACKGROUND}

Cerebrovascular ischemia is recognized as a major health problem, which causes significant morbidity and mortality. The main pathophysiology of ischemic stroke is atherosclerosis of cerebral vessels. Hs-CRP is a sensitive marker of inflammation tissue injury in the arterial wall, which contributes to atherosclerosis. In this study, we aim to investigate the association of hs-CRP in patients with ischemic stroke and to correlate hs-CRP levels with possible risk factors of ischemic stroke and to assess the prognostic value of hs-CRP in ischemic stroke.

\section{METHODS}

In the present case control study after meeting inclusion and exclusion criteria, 50 patients with acute ischemic stroke admitted in the medical ward, King George Hospital, during the period between April 2014 and October 2014 and 40 asymptomatic age and sex matched control subjects were included.

\section{RESULTS}

The mean hs-CRP value in cases is $3.78+5.28 \mathrm{mg} / \mathrm{dl}$ and in controls is $0.425+0.305 \mathrm{mg} / \mathrm{dl}$. Mean hs-CRP value is higher $(3.78 \mathrm{mg} / \mathrm{dl})$ in cases when compared to controls $(0.425 \mathrm{mg} / \mathrm{dl})$, which is statistically significant. $\mathrm{P}<0.05$. The mean age of cases was $56.82+12.94$ years. Out of 50 cases, 39 were male, 11 were female. Out of 40 controls, $30(75 \%)$ were male and $10(25 \%)$ were female. Mean age of controls was $52.75+11.64$ years. Out of 50 cases $12(24 \%)$ were diabetics with mean hs-CRP value of $4.125+4.63 \mathrm{mg} / \mathrm{dl}$; 38 (76\%) were non-diabetics with mean hs-CRP value of $3.668+5.56 \mathrm{mg} / \mathrm{dl}$. $\mathrm{P}=0.417$. Out of 50 cases 43 (86\%) were hypertensive with mean hs-CRP value of $3.99+5.45,7(14 \%)$ were non-hypertensives with mean hs-CRP value of $2.45 \pm 1.74 \mathrm{mg} / \mathrm{dl} . \mathrm{P}=0.301$. Out of 50 cases $20(40 \%)$ were with hyperlipidemia with mean hs-CRP value of $3.12+5.24 \mathrm{mg} / \mathrm{dl}, 30(60 \%)$ were with normal lipid profile with mean hs-CRP value of $4.126+5.44 \mathrm{mg} / \mathrm{dl}$. $\mathrm{P}=0.54$. Out of 50 cases 37 (74\%) were smokers with mean hs-CRP value of $4.29+5.93 \mathrm{mg} / \mathrm{dl}, 13(26 \%)$ were non-smokers with mean hs-CRP value of $2.315+3.31 \mathrm{mg} / \mathrm{dl}$. $\mathrm{P}=0.61$. Out of 50 cases 27 (54\%) were alcoholics with mean hs-CRP value of 4.35+6.04mg/dl, 23 (46\%) were non-alcoholics with mean hs-CRP value of $2.63 \pm 4.67 \mathrm{mg} / \mathrm{dl}$. $\mathrm{P}=0.74$. Out of 50 cases $23(46 \%)$ were admitted with moderate degree of weakness (3-4/5 power) with mean hs-CRP value of $0.66 \pm 0.48 \mathrm{mg} / \mathrm{dl}$, improved at the time of discharge ( $4+/ 5$ to $5 / 5$ power); 19 (38\% $>$ ) admitted with severe degree of weakness $(0-1 / 5$ power $)$ with mean hs-CRP value of $4.28+4.07$ without significant improvement in the power at the time of discharge; $8(16 \%>)$ with mean hs-CRP value of $10.43+7.74$ were expired.

\section{CONCLUSION}

Acute ischemic patients had higher mean hs-CRP values when compared to healthy asymptomatic control subjects $\mathrm{P}<0.005$. There is no statistically significant correlation between mean hs-CRP values and other vascular risk factors like Diabetes mellitus, Hypertension, Hyperlipidemia, Smoking and Alcohol P $>0.05$. Higher mean hs-CRP values were associated with poor outcome after acute ischemic stroke. $\mathrm{P}<0.001$.

\section{KEYWORDS}

Stroke, Cerebrovascular Ischemia, Atherosclerosis, hs-CRP.

HOW TO CITE THIS ARTICLE: Padmalatha P, Neeraja K. High sensitive C-reactive protein in cerebrovascular ischemia. J. Evolution Med. Dent. Sci. 2016; 5(11):453-458, DOI: 10.14260/jemds/2016/104

\section{INTRODUCTION}

Infections and inflammation play a vital role in the pathophysiology of atherosclerosis. High sensitive C-reactive protein (hs-CRP) is a sensitive marker of inflammation and tissue injury in the arterial wall. CRP is a glycoprotein

Financial or Other, Competing Interest: None.

Submission 23-12-2015, Peer Review 17-01-2016,

Acceptance 25-01-2016, Published 05-02-2016.

Corresponding Author:

Dr. Padmalatha $P$,

Flat 201, Coastal Square Apartments,

Official Colony $1^{\text {st }}$ Lane,

Visakhapatnam-530001.

E-mail: padmalathamdgen@gmail.com

DOI: $10.14260 /$ jemds/2016/104 produced by the liver and plays a vital role in the development of atherosclerotic disease in cardiac and cerebral circulation. ${ }^{1}$ $\mathrm{CRP}$, an acute-phase protein synthesised by hepatocytes is released in the blood stream in response to inflammation and tissue damage. ${ }^{2}$ CRP stimulates the endothelial cells to produce various adhesion molecules, such as intracellular adhesion molecule-1, vascular cell adhesion molecule- 1 and Eselectin. These molecules allow migration of mononuclear cells and $\mathrm{T}$ lymphocytes into the vessel wall and play a key role in the formation of atherosclerotic plaque. ${ }^{1}$ CRP also helps in releasing of superoxide anion and stimulation of tissue factor activity. In addition it induces plasminogen activator inhibitor1 (PAI-1); a marker of disrupted fibrinolysis and atherothrombosis. Finally, CRP may increase the chance of endothelial cell lysis and plaque erosion and can precipitate 
acute ischemic stroke or coronary syndrome. All these thus predispose to atherosclerosis in cerebral and cardiac circulation.

Cerebrovascular ischemia has been associated with bronchial and periodontal infections. As a marker of infection and inflammation, high hs-CRP has been associated with acute stroke. Since infectious and inflammatory diseases are more common in India compared to western countries, we aim to investigate the association of high hs-CRP ( $>3 \mathrm{mg} / \mathrm{L}$ ) levels in patients with ischemic stroke and to correlate hs-CRP levels with possible risk factors of ischemic stroke.

\section{MATERIALS AND METHODS}

Fifty patients with acute ischemic stroke admitted in the medical ward, King George Hospital, between April 2014 October 2014 and 40 asymptomatic age and sex matched control subjects were included in the study.

The exclusion criteria were transient ischemic attack, recurrent stroke or second stroke patients, intracerebral haemorrhage, subarachnoid haemorrhage. Patients with clinical symptoms and signs of active infection, patients with inflammatory diseases like rheumatoid arthritis and Systemic Lupus Erythematosus (SLE) and those on steroids or immunomodulatory drugs, salicylates, statins, patients with liver disease, renal disease, any malignancy, myocardial infarction, recent surgery, trauma, chronic rheumatic heart disease were also excluded.

Stroke was defined according to the World Health Organization as "rapidly developing clinical signs of focal/global disturbance of cerebral function with symptoms lasting 24 hours or longer or leading to death with no apparent cause other than of vascular origin." Cerebral infarction was diagnosed on the basis of history, neurological examination and neuroimaging (CT or brain MRI). All patients of ischemic stroke were included.

Forty asymptomatic age and sex matched control subjects were recruited in the study. CT Brain was obtained in all cases. Blood samples were collected at the time of admission and estimated for blood counts, blood sugar, serum creatinine, lipid profile and C-reactive protein. ECG and 2D Echocardiogram were recorded.

All the patients were observed for one week in the hospital. All the controls were subjected to the same investigations.

Measurement of hs-CRP was done in all patients and controls on a fully automated Olympus AU 400 Chemistry Analyzer from Olympus America Inc., USA.

The cardiovascular risk was determined as low risk with hs-CRP levels $<1.0 \mathrm{mg} / \mathrm{L}$, medium risk if $1.0-3.0 \mathrm{mg} / \mathrm{L}$, high risk when $>3.0 \mathrm{mg} / \mathrm{L}$. For our study, we considered hs-CRP level of $\geq 3 \mathrm{mg} / \mathrm{L}$ as high risk and $\leq 3 \mathrm{mg} / \mathrm{L}$ as low risk.

\section{STATISTICAL ANALYSIS}

Date is analysed to calculate Mean and Standard Deviation (SD).

$P$ value $<0.05$ was considered as statistically significant. Results were expressed in the form of tables and charts.

\section{OBSERVATIONS AND RESULTS \\ Males vs Females in cases}

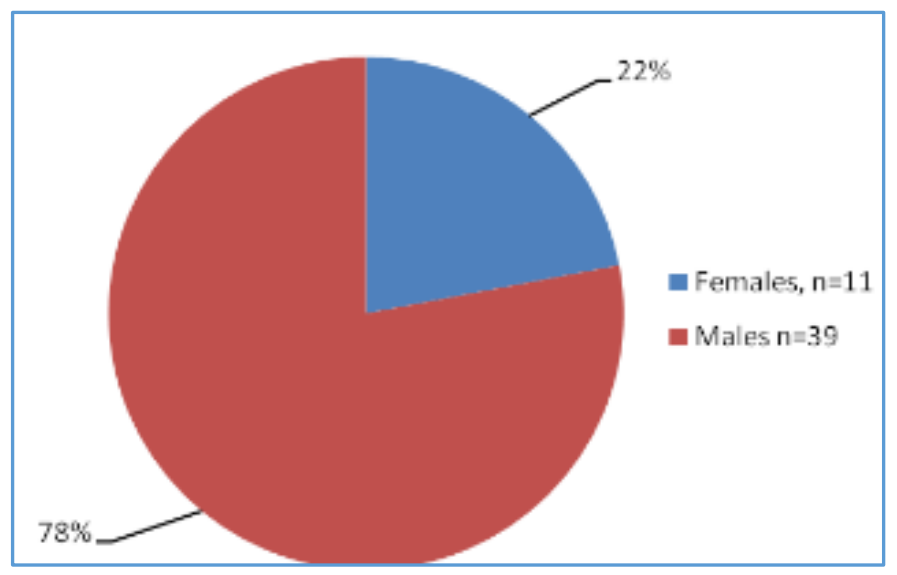

In 50 cases studied, 39 (78\%) were males and 12 (22\%) were females.

\section{Age and Sex Distribution in cases}

\begin{tabular}{|c|c|c|c|}
\hline $\begin{array}{c}\text { Age in } \\
\text { Years }\end{array}$ & $\begin{array}{c}\text { Male No. } \\
\mathbf{( \% )}\end{array}$ & $\begin{array}{c}\text { Female No. } \\
\mathbf{( \% )}\end{array}$ & $\begin{array}{c}\text { Total No. } \\
\mathbf{( \% )}\end{array}$ \\
\hline $31-40$ & $3(75 \%)$ & $1(25 \%)$ & $4(8 \%)$ \\
\hline $41-50$ & $16(100 \%)$ & $0(0 \%)$ & $16(32 \%)$ \\
\hline $51-60$ & $8(62 \%)$ & $5(38 \%)$ & $13(26 \%)$ \\
\hline $61-70$ & $7(70 \%)$ & $3(30 \%)$ & $10(20 \%)$ \\
\hline $71-80$ & $3(60 \%)$ & $2(40 \%)$ & $5(10 \%)$ \\
\hline $81-90$ & $2(100 \%)$ & 0 & $2(4 \%)$ \\
\hline Total & $\mathbf{3 9}(\mathbf{7 8 \% )}$ & $\mathbf{1 1}(\mathbf{2 2 \% )}$ & $\mathbf{5 0}$ \\
\hline
\end{tabular}

Fifty patients of acute ischemic stroke in the age group of $30-90$ years were included in the study. The mean age of cases was $56.82+12.94$ years. Out of 50 cases, 39 were male and 11 were female. Study population age range from 30-86 years. Majority were in the age group 41 to 50 years, all of them were male. Majority of females were in the age

\section{Male vs Females in controls}

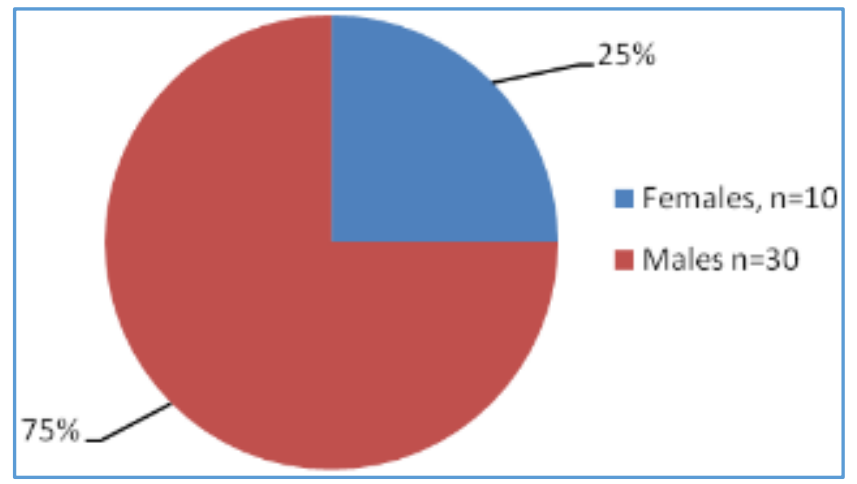

Of the 40 controls, $30(75 \%)$ were male and 10 (25\%) were female group of 51-60 years. 
Age and Sex Distribution of controls

\begin{tabular}{|c|c|c|c|}
\hline $\begin{array}{c}\text { Age in } \\
\text { Years }\end{array}$ & $\begin{array}{c}\text { Male No. } \\
\mathbf{( \% )}\end{array}$ & $\begin{array}{c}\text { Female No. } \\
\mathbf{( \% )}\end{array}$ & $\begin{array}{c}\text { Total No. } \\
\mathbf{( \% )}\end{array}$ \\
\hline $31-40$ & $3(60 \%)$ & $29(40 \%)$ & $5(12.5 \%)$ \\
\hline $41-50$ & $10(77 \%)$ & $3(23 \%)$ & $13(32.5 \%)$ \\
\hline $51-60$ & $12(92 \%)$ & $1(8 \%)$ & $13(32.5 \%)$ \\
\hline $61-70$ & $3(43 \%)$ & $4(57 \%)$ & $7(17.5 \%)$ \\
\hline $71-80$ & $2(100 \%)$ & 0 & $2(5 \%)$ \\
\hline Total & $\mathbf{3 0}(\mathbf{7 5 \% )}$ & $\mathbf{1 0}(\mathbf{2 5 \% )}$ & $\mathbf{4 0}$ \\
\hline
\end{tabular}

Out of 40 controls, $30(75 \%)$ were male and $10(25 \%)$ were female. Mean age of controls was $52.75+11.64$ years. The control population age range from 30-80 years. Majority were in the age group of 41-60 years. Among them majority were male.

\section{Hs-CRP values in cases}

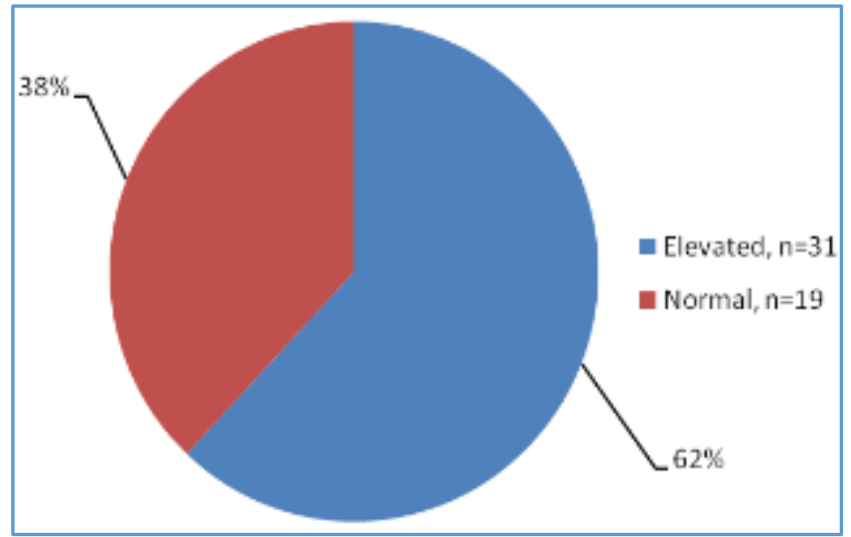

Out of 50 cases, hs-CRP values were normal in 19 (38\%), elevated in 31 (62\%) cases, values ranging from $0.9-22.8 \mathrm{mg} / \mathrm{dl}$ with mean hs-CRP $3.78+5.28 \mathrm{mg} / \mathrm{dl}$.

\section{Hs-CRP values in controls}

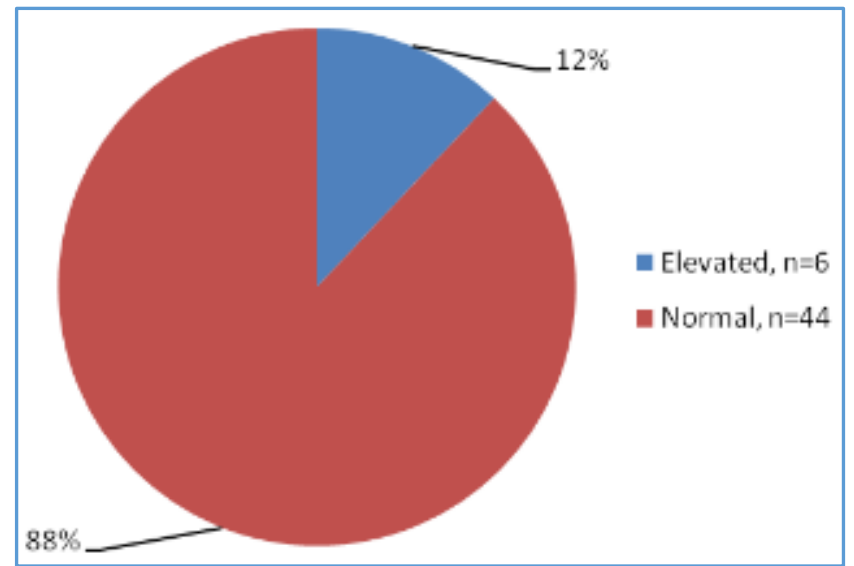

Out of 40 controls hs-CRP values were normal in 44 (88\%), elevated in $6(12 \%)$ values ranging from $0.9-1.7 \mathrm{mg} / \mathrm{dl}$ with mean hs-CRP value $0.425 \mathrm{mg} / \mathrm{dl}+0.305 \mathrm{mg} / \mathrm{dl}$.

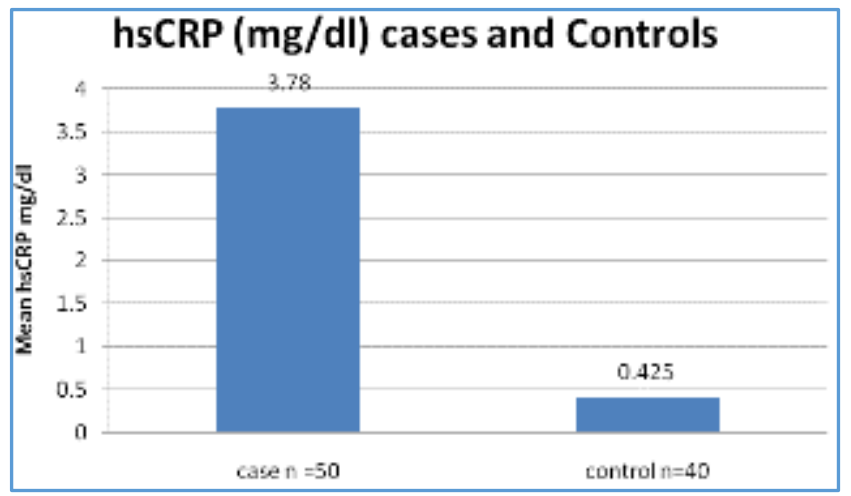

The mean hs-CRP value in cases is $3.78+5.28 \mathrm{mg} / \mathrm{dl}$ and in controls is $0.425+0.305 \mathrm{mg} / \mathrm{dl}$. Mean hs-CRP value is higher $(3.78 \mathrm{mg} / \mathrm{dl})$ in cases when compared to controls $(0.425 \mathrm{mg} / \mathrm{dl})$, which is statistically significant. $\mathrm{P}<0.05$.

\section{Mean hs-CRP values in cases with various Risk Factors}

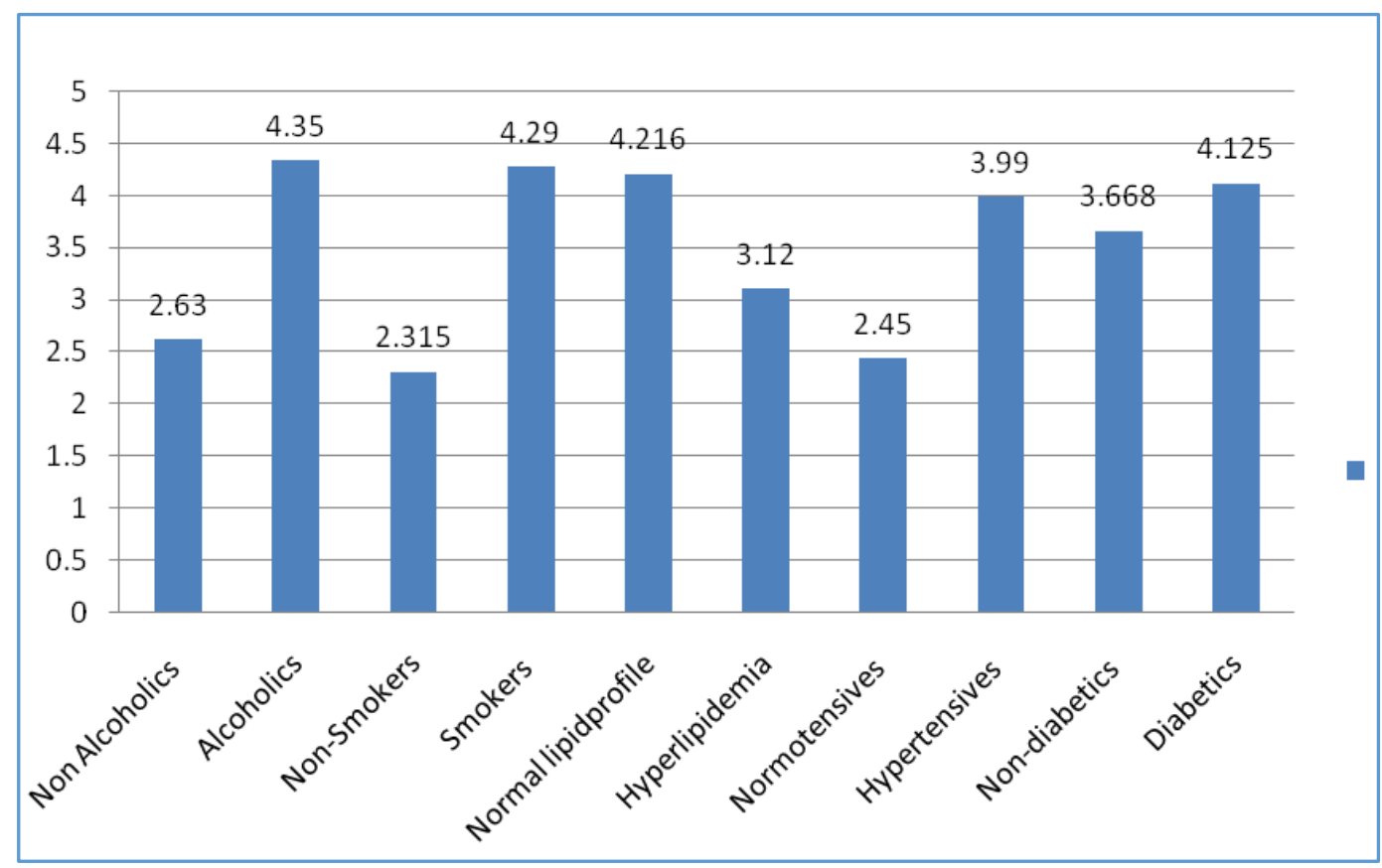


Risk factor groups and hs-CRP values

\begin{tabular}{|c|c|c|c|}
\hline $\begin{array}{c}\text { Risk Factor } \\
\text { Group }\end{array}$ & $\begin{array}{c}\text { No. of } \\
\text { patients }\end{array}$ & $\begin{array}{c}\text { Mean hs-CRP } \\
\text { Values } \\
\text { (mg/dl) }\end{array}$ & P Value \\
\hline $\begin{array}{c}\text { Diabetics } \\
\text { Non-Diabetics }\end{array}$ & $\begin{array}{c}12(24 \%) \\
38(76 \%)\end{array}$ & $\begin{array}{c}4.125+4.63 \\
3.668+5.56\end{array}$ & $\mathrm{P}=0.417$ \\
\hline $\begin{array}{c}\text { Hypertensives } \\
\text { Non- } \\
\text { Hypertensives }\end{array}$ & $\begin{array}{c}43(86 \%) \\
7(14 \%)\end{array}$ & $\begin{array}{l}3.99+5.45 \\
2.45+1.74\end{array}$ & $\mathrm{P}=0.301$ \\
\hline $\begin{array}{c}\text { Hyperlipidemia } \\
\text { Normal lipid } \\
\text { profile }\end{array}$ & $20(40 \%)$ & $3.12 \pm 5.24$ & $\mathrm{P}=0.54$ \\
\hline $\begin{array}{c}\text { Smokers } \\
\text { Non-smokers }\end{array}$ & $37(60 \%)$ & $4.216+5.44$ & \\
\hline $\begin{array}{c}\text { Alcoholics } \\
\text { Non Alcoholics }\end{array}$ & $23(26 \%)$ & $4.29 \pm 5.93$ & $\mathrm{P}=0.68$ \\
\hline
\end{tabular}

Out of 50 cases $12(24 \%)$ were diabetics with mean hsCRP value of $4.125+4.63 \mathrm{mg} / \mathrm{dl} ; 38(76 \%)$ were non-diabetics with mean hs-CRP value of $3.668+5.56 \mathrm{mg} / \mathrm{dl}$. $\mathrm{P}=0.417$. Out of 50 cases $43(86 \%)$ were hypertensives with mean hs-CRP value of $3.99+5.45,7(14 \%)$ were non-hypertensives with mean hs-CRP value of $2.45 \pm 1.74 \mathrm{mg} / \mathrm{dl}$. $\mathrm{P}=0.301$. Out of 50 cases, $20(40 \%)$ were with hyperlipidemia with mean hs-CRP value of $3.12+5.24 \mathrm{mg} / \mathrm{dl}, 30(60 \%)$ were with normal lipid profile with mean hs-CRP value of $4.126+5.44 \mathrm{mg} / \mathrm{dl}$. $\mathrm{P}=0.54$.

Out of 50 cases, 37 (74\%) were smokers with mean hsCRP value of $4.29+5.93 \mathrm{mg} / \mathrm{dl}, 13$ (26\%) were nonsmokers with mean hs-CRP value of $2.315+3.31 \mathrm{mg} / \mathrm{dl}$. $\mathrm{P}=0.61$. Out of 50 cases 27 (54\%) were alcoholics with mean hs-CRP value of $4.35+6.04 \mathrm{mg} / \mathrm{dl}, 23(46 \%)$ were non-alcoholics with mean hsCRP value of $2.63 \pm 4.67 \mathrm{mg} / \mathrm{dl}$. $\mathrm{P}=0.74$.

The difference in mean hs-CRP values among the patients with risk factors and without risk factors was not statistically significant. $\mathrm{P}>0.05$.

\begin{tabular}{|c|c|c|}
\hline Neurological Deficit & $\begin{array}{c}\text { No. of } \\
\text { Patients }\end{array}$ & $\begin{array}{c}\text { Mean hs- } \\
\text { CRP } \\
\text { value mg/dl }\end{array}$ \\
\hline Anterior circulation \\
involvement \\
$\begin{array}{c}\text { Right hemiplegia } \\
\text { Left hemiplegia } \\
\text { Left and Right hemiplegia }\end{array}$ & $47(94 \%)$ & $3.16 \pm 4.76$ \\
\cline { 2 - 3 } & $27(54 \%)$ & $3.40+4.42$ \\
\cline { 2 - 3 } & $19(38 \%)$ & $1.86+2.64$ \\
\hline $\begin{array}{c}\text { Posterior circulation } \\
\text { involvement }\end{array}$ & $3(6 \%)$ & 22.8 \\
\hline
\end{tabular}

In anterior circulation involvement, out of 47 cases 27 (54\%) were with right hemiplegia with mean hs-CRP value of $3.40+4.42 \mathrm{mg} / \mathrm{dl}, 19$ (38\%) were with left hemiplegia with mean hs-CRP value of $1.86+2.64 \mathrm{mg} / \mathrm{dl}$. One case with both right and left hemiplegia, bilateral MCA involvement with mean hs-CRP value of $22.8 \mathrm{mg} / \mathrm{dl}$.

Three cases were with posterior circulation involvement with mean hs-CRP value of $9.37 \pm 10.515 \mathrm{mg} / \mathrm{dl}$. No statistically significant association between hs-CRP values of right and left hemiplegia. $\mathrm{P}>0.05$.

Higher mean hs-CRP values $(9.37+10.515 \mathrm{mg} / \mathrm{dl})$ were observed in posterior circulatory stroke when compared to anterior circulatory stroke $(3.16+4.76 \mathrm{mg} / \mathrm{dl})$. But due to random sampling variability, it is not a statistically significant difference $\mathrm{P}=0.198$.

\section{Distribution of Neurological Deficit in cases}

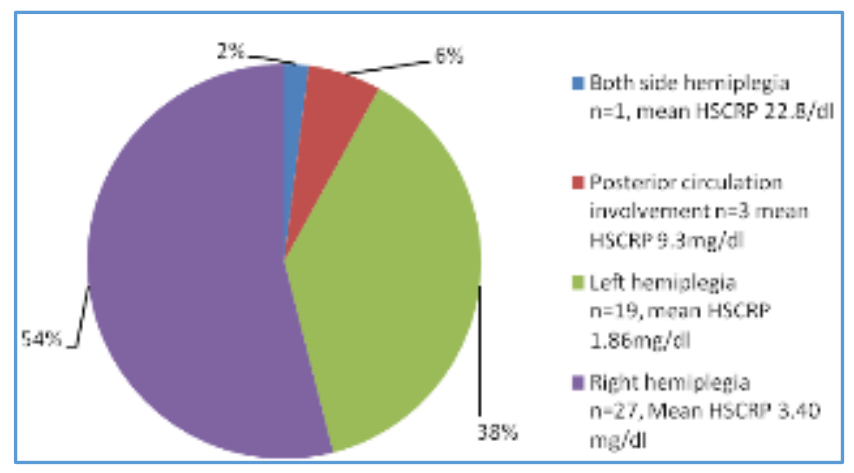

Outcome and Mean hs-CRP value

\begin{tabular}{|c|c|c|}
\hline Power & No. of Patients & Mean hs-CRP mg/dl \\
\hline Improved & $23(46 \%)$ & $0.66 \pm 0.48$ \\
\hline Not improved & $19(38 \%)$ & $4.28+4.07$ \\
\hline Expired & $98(16 \%)$ & $10.43 \pm 7.74$ \\
\hline
\end{tabular}

Out of 50 cases, 23 (46\%) were admitted with moderate degree of weakness (3-4/5 power) with mean hs-CRP value of $0.66 \pm 0.48 \mathrm{mg} / \mathrm{dl}$, improved at the time of discharge $(4+/ 5$ to $5 / 5$ power); $19(38 \%>)$ admitted with severe degree of weakness $(0-1 / 5$ power) with mean hs-CRP value of $4.28+4.07$ without significant improvement in the power at the time of discharge; $8(16 \%>)$ with mean hs-CRP value of $10.43+7.74$ were expired.

There is statistically significant association between hsCRP value is cases of improved and not improved. $\mathrm{P}<0.001$.

\section{Outcome and mean hs-CRP}

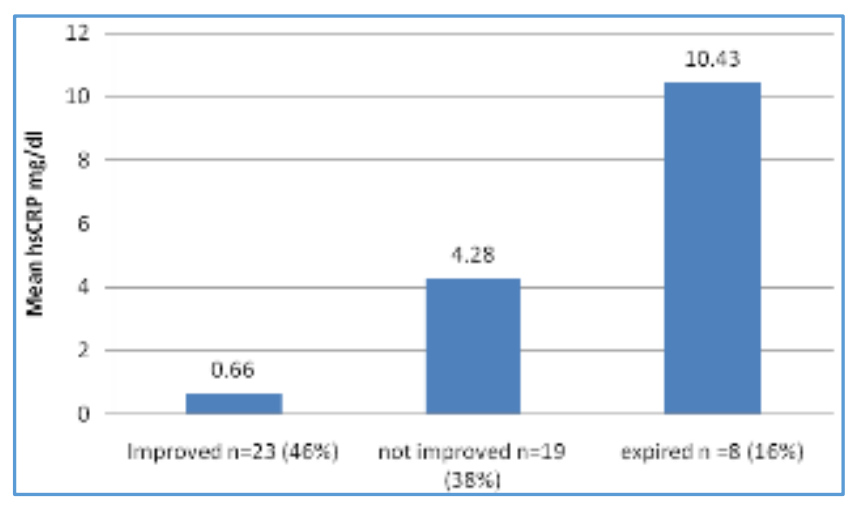

\section{DISCUSSION}

There are several studies where CRP levels were measured in acute myocardial infarction..$^{3}$ unstable angina. ${ }^{4}$ and also unstable angina. ${ }^{5}$ and shown C-reactive protein (CRP) as an independent risk factor. 6

There are studies where C-reactive protein levels were measured in Acute Ischemic Stroke, i.e. Napoli et al. ${ }^{7}$ Abdulkadir, Kocer et al. ${ }^{8}$ Muir et al. ${ }^{9}$ Criag J Smith et al. ${ }^{10}$ and Tahir Yoldas et al. ${ }^{11}$ All the studies have shown that C-reactive protein elevation is an independent predictor of prognosis after ischemic stroke.

Napoli et al. ${ }^{7}$ studied C-reactive protein levels in 193 patients of acute ischemic stroke and followed up to 12 months, observed for combined endpoints, new vascular events or death at 1 year. Serum $\mathrm{C}$-reactive protein was 
measured within 24 hours after the index ischemic stroke, within 48-72 hrs. and at hospital discharge. They examined the association between the level of CRP at different stages after stroke and outcome. CRP at admission (Hazard ratio) HR 2.78; 95\% CI 1.45 to 5.33; $\mathrm{P}=0.0021$ and at discharge HR 9.42; 95\% CI 4.27 to $19.05 ; \mathrm{P}<0.001$ were predictors of combined endpoint of new vascular events or death at 1 year. CRP at hospital discharge was the strongest independent marker of adverse outcome (HR 7.42, 95\% CI 2.75 to 20.03; $\mathrm{P}=0.0001$ ). They concluded that CRP is a marker of increased one-year risk in ischemic stroke.

Keith W Muir et al. ${ }^{9}$ studied survival time and cause of death up to 4 years after the index ischemic stroke and related to CRP concentration within 72 hours of stroke. This study was done in 228 patients of acute ischemic stroke. Survival in those within CRP $>10.1 \mathrm{mg} / \mathrm{L}$ was significantly worse than in those with $\mathrm{CRP}<10.1 \mathrm{mg} / \mathrm{L}, \mathrm{P}=0.0009$. Higher $\mathrm{CRP}$ concentration was an independent predictor of mortality (HR 1:23; 95\% CI 1.13 to $1.35 ; \mathrm{P}=0.02$ ). Cardiovascular disease accounted for $76 \%$ of deaths in those with CRP $>10.1 \mathrm{mg} / \mathrm{L}$ and $63 \%$ of death in those with CRP $<10.1 \mathrm{mg} / \mathrm{L}$. They concluded that CRP concentration is an independent predictor of survival after ischemic stroke.

Tahir Yoldas et al. ${ }^{11}$ studied hs-CRP levels and homocysteine levels in 40 patients of ischemic stroke and 40 control subjects. They measured hs-CRP levels at $2^{\text {nd }}, 5^{\text {th }}$ and $10^{\text {th }}$ day of admission. They observed that the mean hs-CRP levels were higher $\left(9.4,11\right.$ and $9.2 \mathrm{mg} / \mathrm{L}$ on $2^{\text {nd }}, 5^{\text {th }}$ and $10^{\text {th }}$ day respectively) when compared to controls $(1.7 \pm 2.9 \mathrm{mg} / \mathrm{L})$, $\mathrm{P}=<0.001$. They concluded that hs-CRP values were higher in acute ischemic stroke patients, high hs-CRP values were associated with large infarcts and short-term unfavourable prognosis seems to be associated with high hs-CRP values.

Abdulkadir, Kocer et al. ${ }^{8}$ studied hs-CRP levels in acute ischemic stroke patients and relation between hs-CRP levels and clinical outcomes at six months. They enrolled 46 patients of acute ischemic stroke and 26 control subjects. They measured hs-CRP levels within 12-24 hrs. after the index stroke. They observed that levels of hs-CRP were higher in patients $(3.12 \mathrm{mg} / \mathrm{dl})$ than controls $(0.39 \mathrm{mg} / \mathrm{dl})(\mathrm{P}=0.0001)$. They concluded that hs-CRP values were not related to the presence of other vascular risk factors; except for cholesterol level and there was a linear correlation between the serum hs-CRP values, death within 6 months and presence of hypertension $(\mathrm{P}=0.024)$.

Smith et al. ${ }^{10} 2004$, studied 37 patients of acute ischemic stroke. HS-CRP values were measured at admission, $5^{\text {th }}$ and $7^{\text {th }}$ day, followed up to 12 months. They concluded that peak hs-CRP values correlated strongly with stroke severity and infarct volume at 5 and 7 day disability at $3^{\text {rd }}$ and $12^{\text {th }}$ months.

In the present study, 50 cases of acute ischemic stroke admitted in the King George Hospital were studied. Hs-CRP values were measured within $48 \mathrm{hrs}$. of the onset of stroke. In our study maximum age incidence was between $41-50$ years (32\%) with mean age $56.82 \pm 12.94$ years when compared to $73 \pm 9.17$ years of Napoli et al.7; $67 \pm 13$ years of Muir et al; 9 $69.6 \pm 11.4$ years of Abdulkadir, Kocer et al. ${ }^{8}$ studies.

Male:Female ratio was 3.53:1, when compared to $0.7: 1$ of Napoli et al. ${ }^{7}$ study, 0.9:1 of Abdulkadir, Kocer et al. ${ }^{8}$ study.

\begin{tabular}{|c|c|c|}
\hline Study & $\begin{array}{c}\text { Mean Age } \\
\text { (Years) }\end{array}$ & Male:Female \\
\hline Present Study $^{\text {Napoli et al. }}{ }^{2}$ & $56.82 \pm 12.94$ & $3.5: 1$ \\
\hline $\begin{array}{c}\text { Abdulkadir } \\
\text { Kocer et al. }\end{array}$ & $69.6 \pm 11.4$ & $0.7: 1$ \\
\hline Muir et al. $^{9}$ & $67 \pm 13$ & $0.9: 1$ \\
\hline
\end{tabular}

In present study, mean hs-CRP values were higher in cases $(3.78 \mathrm{mg} / \mathrm{dl} \pm 5.28 \mathrm{mg} / \mathrm{dl})$ than in controls $(0.425 \pm 0.305)$, P0.05. Our finding is consistent with other studies, Abdulkadir, Kocer et al. ${ }^{8}$ cases vs controls $(3.12 \mathrm{mg} / \mathrm{dl}$ vs $0.39 \mathrm{mg} / \mathrm{dl})$; Tahir Yoldas et al. ${ }^{11}$ cases vs controls $(9.4 \mathrm{mg} / \mathrm{dl}$ vs $1.7 \mathrm{mg} / \mathrm{dl})$; Muir Keith et al. ${ }^{9}$ cases vs controls $(33.9 \mathrm{mg} / \mathrm{dl}$ vs $4.2 \mathrm{mg} / \mathrm{dl}$ ).

\begin{tabular}{|c|c|c|}
\hline Study & $\begin{array}{c}\text { Mean hs-CRP } \\
\text { cases mg/dl }\end{array}$ & $\begin{array}{c}\text { Mean hs-CRP } \\
\text { controls mg/dl }\end{array}$ \\
\hline Present study & $3.78 \pm 5.28$ & $0.45 \pm 0.30$ \\
\hline $\begin{array}{c}\text { Abdulkadir } \\
\text { Kocer et al. }\end{array}$ & 3 AHA A & $0.39 \pm 0.6$ \\
\hline $\begin{array}{c}\text { Tahir Yoldas et } \\
\text { al.11 }\end{array}$ & $0.94 \pm 0.7$ & $0.17 \pm 0.29$ \\
\hline $\begin{array}{c}\text { Muir Keith et } \\
\text { al. }\end{array}$ & 3.39 & $0.42 \pm 0.19$ \\
\hline
\end{tabular}

In the present study, 43 (86\%) were hypertensives, 12 (24\%) were diabetics, 20 (40\%) were with hyperlipidemia, 37 (74\%) were smokers, 27 (54\%) were alcoholics. In our study, mean hs-CRP values did not show diabetics $(3.66 \pm 5.56 \mathrm{mg} / \mathrm{dl})$ $\mathrm{P}=0.417$; Hypertensives $\quad(3.99 \pm 5.45 \mathrm{mg} / \mathrm{dl})$ and non-hypertensives $\quad(2.45 \pm 1.74 \mathrm{mg} / \mathrm{dl}) \quad \mathrm{P}=0.301$; smokers $(4.29 \pm 5.93 \mathrm{mg} / \mathrm{dl})$ and non-smokers $(2.31 \pm 3.31 \mathrm{mg} / \mathrm{dl})$ $\mathrm{P}=0.68$; Alcoholics $(4.35 \pm 6.04 \mathrm{mg} / \mathrm{dl})$ and non-alcoholics $(2.63 \pm 4.33 \mathrm{mg} / \mathrm{dl}) \mathrm{P}=0.74$ and patients with normal lipid profile $(4.216 \pm 5.44 \mathrm{mg} / \mathrm{dl})$ and hyperlipidemics (3.12 $\pm 5.24 \mathrm{mg} / \mathrm{dl}) \mathrm{P}=0.74$.

In Abdulkadir Kocer et al. ${ }^{8}$ study, they found that mean hs-CRP values were higher in hypertensives $(4.12 \pm 5.82 \mathrm{mg} / \mathrm{dl})$ when compared to other patients $(1.82 \pm 2.30 \mathrm{mg} / \mathrm{dl}) \mathrm{P}=0.024$. The level of hs-CRP was not related to the presence of vascular risk factors except for cholesterol levels $\mathrm{P}=0.003$ and hypertension $\mathrm{P}=0.024$. Our results were consistent with other studies Napoli et al. ${ }^{7}$ Muir et al. ${ }^{9}$ Kerstin Winbeck et al. ${ }^{12}$ where they concluded that hs-CRP is an independent prognostic marker.

In the present study, out of 50 cases 47 (94\%) were with anterior circulatory stroke and $3(6 \%)$ were with posterior circulatory stroke. The mean hs-CRP values did not show statistically significant difference in relation to location of infarct. Mean hs-CRP values in left MCA territory infarcts $3.4 \pm 4.42 \mathrm{mg} / \mathrm{dl}$ and right MCA territory $1.86 \pm 2.64 \mathrm{mg} / \mathrm{dl}$. $\mathrm{P}=0.30$. Higher mean hs-CRP values were observed in posterior circulatory stroke patients $(9.37 \pm 10.515 \mathrm{mg} / \mathrm{dl})$ when compared to anterior circulatory stroke $(3.16 \pm 4.76 \mathrm{mg} / \mathrm{dl})$. It is not statistically significant due to random sampling variability. $\mathrm{P}=0.198$. In Abdulkadir Kocer et al. ${ }^{8}$ study they found that there is no statistically significant relation between mean hs-CRP value and location of the infarct.

In the present study $10(20 \%)$ patients had lacunar infarcts, $40(80 \%)$ had large infracts. We found that there is statistically significant correlation between mean hs-CRP value and size of the infarct; large infarcts $(4.32 \pm 5.85 \mathrm{mg} / \mathrm{dl})$ 
vs lacunar infarcts $(0.54 \pm 0.23 \mathrm{mg} / \mathrm{dl}) . \mathrm{P}=0.003$. Similar results were observed in other studies. Napoli et al. ${ }^{7}$ study $(87.7 \%$ vs $60.3 \% \mathrm{P}=0.004)$, Kerstin Winbeck et al. ${ }^{12}$ study $51.9 \mathrm{ml}(95 \%$ CI, 17.2 to 86.7$)$ vs $13.6 \mathrm{ml}$ [(95\% CI, $0-27.6) ; \mathrm{P}=0.0042]$, Muir Keith et al. ${ }^{9}$ study [( $84 \%$ vs $\left.\left.66 \%\right) \mathrm{P}=0.005\right]$.

In the present study 23 (46\%) were improved, 19 (38\%) were not-improved, 8 (16\%) were expired. We found that there is statistically significant difference in the mean hs-CRP values between improved $(0.66 \pm-0.48 \mathrm{mg} / \mathrm{dl})$ and not improved $(4.28 \pm 4.07 \mathrm{mg} / \mathrm{dl}) . \mathrm{P}<0.001$. Patients who were expired had higher mean hs-CRP value $(10.433 \pm 7.74 \mathrm{mg} / \mathrm{dl})$. Similar results were observed in other studies. In Abdulkadir Kocer et al. ${ }^{8}$ study mean hs-CRP value of expired patients was $9.71 \pm 6.03 \mathrm{mg} / \mathrm{dl}$. In Napoli et al. ${ }^{7}[(39.3 \%$ vs $3 \%) \mathrm{P}=0.0028]$, Kerstin Winbeck et al. ${ }^{12}$ [(14\% vs 3\%) P=0.002], Muir Keith et al. ${ }^{9}$ [(48.9\% vs $\left.\left.26.5 \%\right) \mathrm{P}=0.0009\right]$, studies they found that survival of patients with high hs-CRP values was significantly worse than those with low hs-CRP values.

\begin{tabular}{|c|c|}
\hline Study & $\begin{array}{c}\text { Mean hs-CRP values in } \\
\text { expired patients }\end{array}$ \\
\hline Present study & $10.433 \pm 7.74 \mathrm{mg} / \mathrm{dl} \mathrm{P} 0.001$ \\
\hline Tahir Yoldas et al. ${ }^{11}$ & $14.7 \pm 7.0 \mathrm{mg} / \mathrm{L} \mathrm{P}<0.05$ \\
\hline Abdulkadir Kocer et al. ${ }^{8}$ & $9.71 \pm 6.43 \mathrm{mg} / \mathrm{dl} \mathrm{P}<0.01$ \\
\hline
\end{tabular}

\section{CONCLUSION}

Acute ischemic patients had higher mean hs-CRP values $(3.78+/-5.28 \mathrm{mg} / \mathrm{dl})$, when compared to healthy asymptomatic control subjects $(0.42+/-0.305 \mathrm{mg} / \mathrm{dl}) \mathrm{P}=0.005$.

There is no statistically significant correlation between mean hs-CRP values and other vascular risk factors like Diabetes mellitus, Hypertension, Hyperlipidemia, Smoking, and Alcohol $\mathrm{P}>0.05$.

There is statistically significant association between elevated levels of mean hs-CRP values and size of the infarct. Large infarcts $(4.32+/-5.85 \mathrm{mg} / \mathrm{dl})$ vs lacunar infarcts $(0.54+/-0.23 \mathrm{mg} / \mathrm{dl}) \mathrm{P}=0.003$.

Higher mean hs-CRP values were associated with poor outcome after acute ischemic stroke. Mean hs-CRP values of improved patients was $0.66+/-0.48 \mathrm{mg} / \mathrm{dl}$, not improved was $4.289+/-4.07 \mathrm{mg} / \mathrm{dl}$ and expired was $10.43+/-7.74 \mathrm{mg} / \mathrm{dl}$, $\mathrm{P}<0.001$.

In acute ischemic stroke patient's CRP values were not related to other vascular risk factors like diabetes mellitus, hypertension, hyperlipidemia, smoking and alcohol. Hence, estimation of hs-CRP is an independent marker in assessment of severity of the stroke and predicting short-term prognosis.

In the Jupiter trial, statins decreased the risk of myocardial infarction and ischemic stroke in patients with high hs-CRP levels. Thus, high hs-CRP levels may be a marker for starting therapy with statins for both primary and secondary prevention. Future large scale studies are required to explore these findings.

\section{REFERENCES}

1. Evaluation of C-reactive protein measurements for assessing the risk and prognosis in ischemic stroke by: $\mathrm{Di}$ Napoli, Markus Schwaninger. Stroke. 2005;1318-1328.

2. Fundamentals of clinical chemistry by Carl A Burtis, Edward R Ashwood, David E Bruns. $6^{\text {th }}$ edition; pp 427$428,301$.

3. Berk BC, Weintraub WS, Alexander RW. Elevation of Creactive protein in "active" coronary artery disease. Am J Cardiol 1990;65:168-172.

4. Liuzzo G, Biasucci LM, Gallimore JR, et al. The prognostic value of $\mathrm{C}$-reactive protein and serum amyloid A protein in severe unstable angina.

N Engl J Med 1994;331:417-424.

5. Thompson SG, Kienast J, Pyke SD, et al. for the European Concerted Action on Thrombosis and Disabilities Angina Pectoris Study Group. Hemostatic factors and the risk of myocardial infarction or sudden death in patients with angina pectoris. N Engl J Med 1995;332:635-641.

6. Mendall MA, Patel P, Ballam L, et al. C-reactive protein and its relation to cardiovascular risk factors: a population based cross sectional study. BMJ 1996;312:1061-1065.

7. Di Napoli M, DI Gianfilippo G, Sollecito A, et al. C-reactive protein and outcome after first ever ischemic stroke. Stroke 2000;31:238-239.

8. Abdulkadir Kocer, Cuneyt Canbulat, Eren Gozke, et al. Creactive protein is an indicator for fatal outcomes in first time stroke patients. Med Sci Monit 2005; pp 540-544.

9. Muir KW, Weir CJ, Alwan W, et al. C-reactive protein and outcome after ischemic stroke. Stroke 1999;30:981-985.

10. Smith CJ, Emsley HE, et al. Peak plasma IL-6 and other peripheral markers of inflammation in the first week of ischemic stroke. Correlate with brain infarct volume, stroke severity, long-term outcome. BMC Neurology, 2004; $4: 2$

11. Tahir Yoldas, Murat Gonen, et al., Turkey. The serum high sensitive C-reactive protein and homocysteine levels to evaluate the prognosis of acute ischemic stroke. Mediators of Inflammation Yo $\backslash 20 \mathrm{Ql}, \mathrm{p}$ 1-5.

12. Kerstin Winbeck, MD; Holger Poppert, MD. Prognostic relevance of early serial C-reactive protein measurements after first ischemic stroke: Stroke. 2002;33:2459-2464. 